\title{
The Dynamic of Move in Teacher-Students' Interaction
}

\author{
Aprilza Aswani ${ }^{1}$ \\ ${ }^{1}$ Politeknik Negeri Medan, Indonesia \\ (aprilzaaswani@polmed.ac.id)
}

\begin{abstract}
The present study attempts to determine move dynamics types in teacherstudent's interaction. The research design employed in this study was qualitative content analysis. The data obtained were the form of utterances gained from teacher-student's interaction in English classroom interaction from the secondyear students of SMA Negeri 1 Tanjungbalai class XI IPA 1-3 totaling to 90 students and 3 teachers involved. The data were analyzed by following Martin's framework of move in systemic functional linguistic theory. The findings of the study exhibit that there are three types of move dynamic found in teacherstudent's interaction namely clarification ( $\mathrm{cl})$-response to clarification ( $\mathrm{rcl})$, confirmation ( $\mathrm{cf}$ )-response to confirmation ( $\mathrm{rcf}$ ), and challenge (ch)-response to challenge ( $\mathrm{rch}$ ). The dynamic of move realized in the data happens due to some reasons such as the unclear information from the teacher, and the prior knowledge possessed by students. The findings imply that a teacher should consider having a dynamic interaction. This can help support the achievement of students' success in the teaching-learning process. The dynamic of interactions in the form of clarification, confirmation, and challenge shows that students follow and comprehend the meaning uttered by student.
\end{abstract}

Keywords: move; classroom discourse; Martin's model of interaction.

Text is also called as discourse and it is applied in any medium as well as making sense to those who are knowledgeable (Ganie et al., 2020; Hanafiah et al., 2018). It is also used as a means of communication (Humaizi et al., 2020; Ritonga \& Yusuf, 2020). Spoken discourse is regarded to be more complex rather than written discourse (Eggins, 2004; Hanafiah, 2018). Moreover, spoken text is characterized to grammatically intricate and written text is characterized as lexically densed (Halliday \& Matthiessen, 2004; Zein et al., 2020).

The interaction among the teachers and students as the process of transferring knowledge is inevitable as one of classroom activity (Lizama, 2017) and crucial to determine the quality of teaching-learning process (Pennings et al., 2018). This becomes so essential in achieving the objective of the learning (Suparman \& Charmilasari, 2017). 
The teacher is demanded to have good discourse and enable students to communicate in English.

Systemic functional linguistics (hereafter SFL) is one of approaches that observes language as the meaning-making resources and it has 3 types of meaning which has the same status called as metafunction (Zein et al., 2019). Those are ideational function (experiential and logical function), textual function (clause as message), and interpersonal function (clause as exchange) (Eggins, 2004; Halliday \& Matthiessen, 2014). The interaction among the teacher and students can be explored by those three metafunction. In this study, the interaction is explored by using interpersonal function.

Classroom discourse analysis has an important role in development of students' skill in communication (Rymes, 2008). This becomes so complex since it involves many people and flows fast (Komarawan, 2019). In classroom situation, discourse is understood as the connection between classroom context and language (McCarthy, 1991). Some phenomenon can happen such as the use of metaphor (Casebeer, 2015), the use of code-mixing and code-switching, the use of politeness, etc. The discourse in the classroom should be meaningful due to some reasons such as the successfulness of transferring knowledge and the increase of students' understanding about the materials.

Some experts have explored the classroom discourse. Sinclair \& Coulthard (1975) propose the discourse structure analysis called "Initiation-Response-Feedback" (IRF) model which has structures called teacher elicitation, student response and teacher feedback. Other expert also proposes another model of classrrom discourse analysis. The theory of exchange structures based on interpersonal metafunction in SFL was developed by Martin, (1992). He explains that there are nine exchange of move, namely information, goods and services exchanges. Each exchange have pattern inside. Then, he clarifies that $\mathrm{dk} 1, \mathrm{k} 2$ and $\mathrm{k} 1$ is normally structures of giving and asking for information. The model of analysis used in this study was (Martin, 1992) model in classroom discourse analysis. The move of discourse is under the interpersonal metafunction which is analyzed by three multilayer aspects, namely speech function, Mood and move. To analyze the move of conversation, it must be known speech function and Mood firstly. The move of discourse is discussed under the interpersonal metafunction (clause as exchange) as one of language metafunction in systemic functional linguistics (SFL). Halliday \& Matthiessen (2004) points out two basic interactive distinctions namely language utilization to exchange information and using it to exchange goods and services. Those two interactive distinction construct four types of speech function. The example of move analysis is presented in Table 1.

There are some researches dealing with classroom discourse analysis. Lai (2010) in his research attempts to explore teacher's discourse through evaluative language. Applying appraisal from interpersonal function in SFL, he states that the evaluative discourse used by teacher is applicable in order to build the interaction with students and trigger the students to improve their achievement. He adds that this has one goal that is to maintain good relationship of teacher and student. Fikri et al. (2014) in their research describe the structure of Mood in EFL classroom setting in Indonesia based on gender perspective. Using SFL framework, they argue that cultural and social factors contribute to the Mood structure realization in classroom discourse. Male and female teachers have differences in choosing the code to realize interpersonal function to students. Rangkuti et al. (2018) explore the discourse difference in the classroom from gender perspective. Using speech function analysis, they draw conclusion that the lecturers still domineer the interaction rather than student. They more argue that gender significantly plays role in determining the types of speech function 
Table 1. Move Analysis Example

\begin{tabular}{|c|c|c|c|}
\hline Move & Utterances & Mood & $\begin{array}{l}\text { Speech } \\
\text { Function }\end{array}$ \\
\hline $\mathrm{k} 2$ & Teacher: Do all of you have the paper? & Interrogative & Question \\
\hline $\mathrm{k} 1$ & Students: Yes, mam. & El. Dec & RSQ \\
\hline & T: Now we start our lesson. We are & Declarative & Statement \\
\hline & S: Noun clause, Mam? & Interrogative & Question \\
\hline rcl & $\mathbf{T}:$ Yes & El. Dec & RSQ \\
\hline & & Interrogative & Question \\
\hline
\end{tabular}

realized in classroom setting. Hussein et al. (2020) investigate teacher-student's interaction based on code-switching phenomenon. They argue that this phenomenon is inevitable thing and has been discusess worlwide in multicontext. In relation to the fact stated in advance, this study has the objectives to discover the types of move and to explain why those patterns realized in classroom discourse.

\section{Conversation Analysis}

The term conversation is familiar as it commonly happens in human life. Conversation can be chanelled in many mediums such as direct conversation, phone conversation, classroom conversation, etc. Martin (1992) adds that conversational analysis has nine exchange of move, namely exchange information and exchange goods and services. Conversation sometimes can not run smoothly as well, it can be found the dynamic of conversation, namely clarification, confirmation and challenge. It can be concluded that conversation is dynamic and It always occurs in daily life.

\section{Teacher-Student Interaction}

The definition of teacher talk is very simple and self-evident. But the ways of teacher talk and its influences on the students are the most important. Teacher-student interaction is the subject which involves society, psychology, pedagogy and foreign language teaching, and yet it refers to all kinds of interaction and interactive influence between teachers and students during the whole session of teaching and learning process (McCarthy, 1991).
Teacher-student interaction in classroom means the dynamic progress of the interactive exchange, talk, action and influence between teachers and students in classroom (Sinclair \& Coulthard, 1975). In language classes such as English as Foreign/Second Language, it aims at improving the learners' ability in language use, promoting positive attitude, and developing knowledge of the language systems. To achieve those goals, interaction or communication among the participants is inevitable.

By using teacher talk, teachers can manage activities in order to help the learners. In addition, the teachers can use the language as a means for some activities including explaining, instructing, providing feedback, and so on (Martin, 1992). No matter how teacher talk was divided, it did not make a big difference. The most important thing is the characteristics and influences of teacher talk, they are: (1)how teachers modify their language in order to make themselves understood, (2) how teachers use questions and the questions skills, (3) how teachers give feedback, and (4) how teachers spend talking time, which are discussed as classroom discourse (Sinclair \& Coulthard, 1975).

Classroom discourse is the term which is defined as the language employed or uttered by the participants in classroom inclusding teacher and students. The language is utilized as medium of communication among them. The discourse itself may vary based on the field of study. When the subject is different, the form of the discourse is possibly different. Even, when the type of the school is different for example 
religious school, the discourse employment may different. Teacher uses discourse to obtain things (Sinclair \& Coulthard, 1975). Classroom discourse is unique in its circumstance due to the unequal power between teacher(T) and students (Ss). The unequal status as the realization of tenor significantly affect the discourse (Eggins, 2004).

\section{Interpersonal Meaning in SFL}

As an approach, SFL observes language in social context. Based on this approach, language itself possesses meaning regarded as language metafunctions. This approach sees language as (a) representation; (b) exchange; and (c) organized experience. In the classroom setting, this approach can be used to observe meaning creation within discourse. These metafunction is regarded as ideational, interpersonal and textual (Halliday \& Matthiessen, 2014).

In SFL approach, language is seen as making meaning resource. The language use in inseparable from the context surrounding it. Different circumstance definitely construct different meanings. Language used in hospital will be dissimilar to language used in restaurant. So, it is crystal clear that systemic linguists argue that society and language are closely related.

In SFL, interpersonal meaning is part of metafunction dealing with clause as exchange (Alhamdany, 2016; Eggins, 2004; Halliday \& Matthiessen, 2014). This meaning is the realization of tenor in the context of situation. It discusses the participants relationship in interaction. This function sees language as a tool to encode interaction. Other opinion is that this meaning concerned with social relationships as they are realized in text, that is the interaction between the speaker and the interlocutor (Yuliati, 2013). This function covers the clause exploration through speech function, Mood, modality. So, this function obviously sees the role of the participants in interaction.

\section{Martin's Model of Interaction Analysis}

Martin (1992) asserts that move realization deals with speech function and Mood. The conversation is built in terms of Move. In this way, conversations are multidimensionally analyzed. Move refers to the function or role played by a speaker (addresser) in a conversation in his/her relation to the function or role played by the hearer (addressee) and the commodity being exchanged.

Halliday's theory on move concerns on the terms of nine types involving $\mathrm{k} 1$ (primary knower), k2 (secondary knower), dk1 (delayed knower 1), k1f (delayed knower 1 follow up), k2F (secondary knower follow up), a1 (primary actor), a2 (secondary author), da1 (delayed primary actor), alf (primary author follow up), a2f (secondary actor follow up) which involves to exchange information and exchange goods and services (Halliday \& Matthiessen, 2014). However, sometimes there are pattern of move which do not appeared in conversation or there are other representation.

\section{Conversation Dynamic}

In conversation, sometimes it can run smoothly (static) and have some dynamic in some condition. The dynamic of conversation can be influenced by some reasons. (Martin, 1992) divides dynamic of conversations into three areas namely clarification, confirmation and challenge. Those type has each pair such as clarification (cl)-response to clarification ( $\mathrm{rcl}$ ), confirmation (cf)-response to confirmation (rcf), and challenge(ch)-response to challenge (rch).

Clarification takes the experiential meaning of a previous turn and elaborates it in specific ways (Martin, 1992). It can occur if someone wants to clarify clearly another people's words. Clarification has a pair, it is response to clarification which is a response to answer the clarification in advance. It always occurs in daily conversation. The example of clarification and response to clarification can be illustrated in Table 2 . 
Table 2. The Example of Clarification (cl) and Response to Clarification ( $\mathrm{rcl}$ )

\begin{tabular}{ll}
\hline Move & \multicolumn{1}{c}{ Utterances } \\
\hline k2 & Customer : What time will this restaurant open? \\
$\mathrm{rcl}$ & Receptionist : weekdays or weekend? \\
$\mathrm{k} 1$ & Client : Weekend
\end{tabular}

Martin (1992) describes that confirmation may replay experiential meaning, of a falling or rising tone where the repetition shows that in fact the experiential meaning of the preceding move has been misheared, it will be replayed, giving rise to sequences. The pair of confirmation is response to confirmation which has function to give a response back to answer the confirmation or to replay. The example of confirmation and response to confirmation can be illustrated in Table 3 .

Table 3. The Example of Confirmation (cf) and Re-

\begin{tabular}{|c|c|}
\hline$\overbrace{\mathrm{rcf}}^{\mathrm{c} 2}$ & $\begin{array}{l}\text { Utterances } \\
\text { A: Do you have a pen? } \\
\text { B: ---What? } \\
\text { A: --- Do you have a pen? } \\
\text { B : ---Yes }\end{array}$ \\
\hline
\end{tabular}

Martin (1992) asserts that challenge is type of interruption to be considered interpersonally. This dynamic has a pair, namely response to challenge which is to give a response for the interruption in giving challenge in advance. The example of challenge and response to challenge can be illustrated in Table 4.

Table 4. The Example of Challenge (ch) and Response to Challenge ( $\mathrm{rch}$ )

$\begin{array}{ll}\text { Move } & \text { Utterances } \\ \text { kl } & \text { A: I bet PSG will be the champion. } \\ \text { ch } & \text { B: Are you kidding me? } \\ \text { rch } & \text { A: Maybe } \\ \text { k2f } & \text { B: I even choose Bayern. }\end{array}$

\section{Method}

This study has the objectives to discover the types of move and to explain why those patterns realized in classroom discourse. In order to achieve the objective of this study, qualitative content analysis method was employed. This method is regarded as suitable for this research.

The data were obtained from the interaction among teacher and students in English subjects in SMA Negeri 1 Tanjungbalai from class XI IPA1-3 totaling to 90 students and 3 teachers involved were in the form of utterances. The samples were chosen purposively. The data were recorded from their interaction for an hour and 30 minutes of each class. Before recording, the permission has been obtained from the headmaster, teachers, and students. In collecting the data, the researchers were not present in the classroom in order to get the naturalness of the interaction. The recorder was put in front of the class so that the students and the teacher were not disturbed and they were not aware of being recorded.

After getting the recorded data, the utterances were transcribed manually separating the sentences based on the speaker. The data were coded teacher (T), student (S1, S2, S2.......). The data were analyzed by following the model proposed by Miles et al. (2014) and the theory of move based on Martin (1992) model in systemic functional linguistics. The analysis was started from determining the speech function and Mood first before defining the Move. In gaining the data reliability, triangulation technique was used by involving two experts that have doctoral degree and the research interests are SFL and conversational analysis.

\section{Results and Discussion Results}

Based on the analysis following Martin (1992) framework, those three types of dynamic of move appear in the teacherstudent's interaction. The three of them is 
developed to be six type, they are actually the pairs of clarification, confirmation and challenge, namely clarification $(\mathrm{cl})$ - response to clarification ( $\mathrm{rcl}$ ), confirmation (cf) response to confirmation ( $\mathrm{rcf}$ ), and challenge (ch) - response to challenge ( $\mathrm{rch})$. It is also called as tracking moves. The details of the occurrences are explained in the following parts.

\section{Clarification (cl) and Response to Clarification (rcl)}

Clarification and response to clarification are the first position taken from the data which has appeared in the text. The example of clarification can be presented in Table 5.

Table 5. The Example of Clarification (cl) and Response to Clarification ( $\mathrm{rcl})$

\begin{tabular}{rll}
\hline Move & Utterances & $\begin{array}{l}\text { Typical of } \\
\text { dynamic }\end{array}$ \\
\hline k2 & T: Cici Mustika & Clarification \\
$\mathrm{k} 1$ & S: Sick, miss & and Response \\
cl & T: Is there her letter? & to Clarification \\
rcl & S: Yes, miss & \\
k2f & T: Give it to me & \\
\hline
\end{tabular}

Clarification takes the experiential meaning of a previous turn and elaborates it in specific ways (Martin, 1992). It has a function to clarify something which is give information to others. As an example above, clarification can appear because the teacher wanted to know more about a student who did not come at that moment as stated "Is there her letter?", and the student answer or give the response to clarification as stated "yes, miss".

\section{Confirmation (cf) and Response to Confirmation ( $r c f$ )}

This is the second type of dynamic of conversation which has appeared in the text. The example of confirmation can be seen in Table 6.

Confirmation is one of the dynamic of conversation which always occur in a talking.
Table 6. The Example of Confirmation (cf) and Response to Confirmation (rcf)

\begin{tabular}{rlr}
\hline Move & \multicolumn{1}{c}{ Utterances } & Typical of dynamic \\
\hline $\mathrm{dk} 1$ & $\mathrm{~T}$ : First one is using simple past tense, then... & Confirmation and \\
$\mathrm{k} 2$ & S: using nouns & Response to \\
cf & $\mathrm{T}$ : Example? & Confirmation \\
rcf & S: The name of animal or person is like the & \\
cat or the mice & \\
$\mathrm{k} 1$ & $\mathrm{~T}:$ Yes, good.
\end{tabular}

Martin (1992) describes that confirmation may replay experiential meaning, of a falling or rising tone where the repetition shows that in fact the experiential meaning of the preceding move has been misheard, it will be replayed, giving rise to sequences. As an example in utterances above, the teacher give the confirmation after the student answer her question in advance, then the teacher directly give a question to confirm that the student really know what the student answer the question in advance as stated "example?". The student answer again to give response to confirmation from the teacher as stated in utterance "The name of animal or person is like the cat or the mice".

\section{Challenge (ch) and Response to Challenge (rch)}

It is the last type of dynamic of conversation and the last position in the data. The example can be seen in Table 7 .

Table 7. The Example of Challenge (ch) and Response to Challenge (rch)

\begin{tabular}{clc}
\hline Move & \multicolumn{1}{c}{ Utterances } & Typical of dynamic \\
\hline k1 & $\begin{array}{l}\text { T: I do hope that all of you really understand } \\
\text { what Narrative is. What is the definition, } \\
\text { purpose, structure of the text, and the } \\
\text { grammatical features itself? And I do hope, } \\
\text { you can answer all of questions in this } \\
\text { ch }\end{array}$ \\
assignment. \\
Masitoh: Miss, the papers will be given back \\
to us, right? \\
T: Yes, I will give all of your papers next \\
meeting. \\
S: Thank you, miss
\end{tabular}

As an example above, when the teacher gives an advice to the student before closing the meeting. Suddenly one of student gives interrupt to know whether the papers will be given back or not. That is called challenge. If there is a challenge (ch), there will be response 
to challenge (rch). In utterances, the teacher give the response to challenge as stated "Yes, I will give all of your papers next meeting".

\section{Discussion}

The dynamic of moves possible to happen in classroom discourse. For example, when teacher gives a statement, but students do not hear clearly, of course students will confirm to the teacher. This is done in order to keep the continuity of the interaction and in order to achieve the goal of the teaching. In addition, it is supported that the dynamic pattern of move can realize due to the context surrounding it. In SFL, discourse is inseparable from the context (Eggins, 2004; Halliday \& Matthiessen, 2014).

In giving evaluation, the teacher uses clarification in order to check the students' understanding. By clarifying, the teacher can measure whether the students comprehend the material or not. The teacher can use clarification and conversely, students reply coded as response to clarification. This action is also one of evaluative forms. The teachers utilize evaluative discourse as the instructions to see students' class performances and it is the realization of interpersonal relationship (Lai, 2010).

The other form appear is the challenge and response to challenge pattern. The teacher has instructed the students to interrupt her if there is unclear information or they need to ask something in the middle of explanation. It is supported by Martin (1992) that challenge is a kind of interruption to be considered interpersonally. So, the teacher should reply to this challenge by giving response to challenge. It is appropriate since students need to observe the topic discussed as well as and teacher reply to help them comprehent (Setialis \& Lukmana, 2018).

The dynamic pattern of move is common to happen. This can be triggered by some conditions such as the unclear information from the teacher, and the prior knowledge possessed by students. In Indonesian context, it is also related to the approach used namely student-centred learning which needs frequent students' involvement in teaching-learning process. The dynamic of move simply shows the active involvement of teaching-learning process. The other fact is the teacher and the students cooperatively maintain the interaction by realizing the dynamic of move.

\section{Conclusion}

After analyzing the data, the conclusions can be drawn that the dynamic conversation found in teacher-student interaction are clarification (cl)-response to clarification ( $\mathrm{rcl}$ ), confirmation (cf)-response to confirmation ( $\mathrm{rcf}$ ), and challange (ch)-response to challenge (rch). The dynamic of move may happen due to some reasons such as the unclear information from the teacher, and the prior knowledge possessed by students.

In relation to the conclusion, it is suggested that the teacher should know that interaction sometimes not static and have the dynamics. This can be used as the indicator of the students' involvement and the successfulness of teaching-learning process. The dynamic of interactions in the form of clarification, confirmation, and challenge shows that students follow and comprehend the meaning uttered by student.

This study is limited to the interaction among teacher and students in classroom in which students have various background such as culture and religion. It is critical for further studies to explore the interaction pattern in classroom who has other background such as religious school. Then, further researcher can observe students'attitude towards the teacher's discourse and its effect to students' engagement. In Indonesia, there are also some schools labelled as international school which employ native speakers of English as the teacher and it opens the opportunity to see the comparison of the discourse used by 
native and non-native speaker of English in teaching English in Indonesia.

\section{Acknowledgment}

This paper is part of the master thesis done by corresponding author in Universitas Sumatera Utara. The writers sincerely address their thankfulness to the teachers and students of SMA Negeri 1 Tanjungbalai, Indonesia who participated in this research. Then, the gratitude goes to Prof. T. Silvana Sinar, Ph.D. and Prof. Dr. Ridwan Hanafiah, M.A. who sincerely supervised the writer during her study.

\section{References}

Alhamdany, H. (2016). The usefulness of systemic functional grammar and its impact on students' communicative skills in ESL context. European Scientific Journal, 8(11), 176-194.

Casebeer, D. (2015). Mapping preservice teachers' metaphors of teaching and learning. International Journal of Learning, Teaching and Educational Research, 12(3), 13-23.

Eggins, S. (2004). An Introduction to Systemic Functional Linguistics (2nd ed.). Continuum.

Fikri, Z., Dewi, N., \& Suarnajaya, W. (2014). Mood structure analysis of teacher talk in EFL classroom: A discourse study based on systemic functional linguistic theory. E-Journal Program Pascasarjana Universitas Pendidikan Ganesha, 2, 1-12.

Ganie, R., Sinar, T. S., Deliana, \& Yusuf, M. (2020). Reference markers in introduction section of undergraduate students' theses: A corpus-based systemic functional analysis. Talent Development and Excellence, 12(1), 3998-4006.

Halliday, M. A. K., \& Matthiessen, C. M. I. M.
(2004). An Introduction to Functional Grammar (3rd ed.). Hodder Education.

Halliday, M. A. K., \& Matthiessen, C. M. I. M. (2014). Introduction to functional grammar (4th ed.). Routledge.

Hanafiah, R. (2018). An analysis of lexical density and grammatical intricacy in thesis abstract of English department student of USU. The Asian EFL Journal, 20(7), 130-134.

Hanafiah, R., Yusuf, M., \& Aswani, A. (2018). Theme markedness in EFL students' recount texts: A systemic functional analysis. Southeast Asia Language Teaching and Learning (SALTeL) Journal, 1(1), 14-20.

Humaizi, Ritonga, S. H. N., Asmara, S., \& Yusuf, M. (2020). Positive and negative politeness strategies used in the house of representative members' discourse: A case study in Medan, Indonesia. International Journal of Advanced Science and Technology, 29(5), $6391-6399$.

Hussein, R. F., Saed, H. A., \& Haider, A. S. (2020). Teachers and students codeswitching: The inevitable evil in EFL classrooms. International Journal of Learning, Teaching and Educational Research, 19(2), 60-78. https://doi. org/10.26803/ijlter.19.2.5

Komarawan, Y. (2019). Constructing interpersonal meaning in Indonesian science classrooms through language, space and gaze. Kemanusiaan the Asian Journal of Humanities, 26(1), 1-23. https://doi.org/10.21315/kajh2019.26.1.1

Lai, J. (2010). Interpersonal functions of EFL teachers' evaluative discourse. International Education Studies, 3(2), 167-173. https://doi.org/10.5539/ies. v3n2p167

Lizama, M. V. (2017). Knowledge in your 
classroom: A model of analysis for specialization codes in classroom discourse. Onomázein Revista de Lingüística, Filología y Traducción, Número Especial LSF, 149-178. https:// doi.org/10.7764/onomazein.sfl.06

Martin, J. R. (1992). English Text: System and Structure. John Benjamins.

McCarthy, M. (1991). Discourse analysis for language teachers. Cambridge University Press.

Miles, M. B., Huberman, A. M., \& Saldana, J. (2014). Qualitative data analysis: A methods sourcebook (3rd edition). Sage.

Pennings, H. J. M., Brekelmans, M., Sadler, P., Claessens, L. C. A., van der Want, A. C., \& van Tartwijk, J. (2018). Interpersonal adaptation in teacher-student interaction. Learning and Instruction, 55, 41-57. https://doi.org/10.1016/j. learninstruc.2017.09.005

Rangkuti, U. M., Saragih, A., \& Husein, R. (2018). Speech Functions of Male and Female Lecturers in the Classroom Interaction. Advances in Social Science, Education and Humanities Research, 200, 81-84.

Ritonga, M., \& Yusuf, M. (2020). Diction choice and stylistic editing in the translation of Rapunzel texts: An intralingual translation study. International Journal of Scientific \& Technology Research, 9(4), 2935-2940.

Rymes, B. (2008). Classroom discourse analysis: A tool for critical reflection. Hampton Press.

Setialis, A., \& Lukmana, I. (2018). Teacher talk realization in observing stage of scientific approach: An interpersonal meaning analysis of EFL classroom discourse. Edulitics Journal, 3(1), 29-35.

Sinclair, J., \& Coulthard, M. (1975). Towards an analysis of discourse. Heinle \& Heinle.
Suparman, \& Charmilasari. (2017). Analysis of phase structure realization in classroom discourse: A study of systemic functional linguistics. Ethical Lingua, 4(1), 120-126.

Yuliati. (2013). Interpersonal meaning negotiation in the teacher-student verbal interaction. The International Journal of Social Sciences, 11(1), 52-60.

Zein, T T, Sinar, T. S., Nurlela, N., \& Yusuf, M. (2019). The Incomplete linguistic features and schematic structure in EFL university students' narrative texts. Journal of Education, Teaching and Learning, 4(1), 203-209. https://doi. org/10.26737/jetl.v4i1.675

Zein, T T, Sinar, T. S., Nurlela, \& Yusuf, M. (2020). Assessing Complexity in the Introduction Part of Bachelor's Theses: A Systemic Functional Linguistic Framework. Talent Development \& Excellence, 12(1), 2100-2111. http:// www.iratde.com/index.php/jtde/article/ view/822/634 